\begin{tabular}{lcccr} 
T H E & A R C H I V E & O F & M E C H A N I C A L & E N G I N E E R I N G \\
\hline VOL. LVII & 2010 & Number 4
\end{tabular}

10.2478/v10180-010-0019-6

Key words: hydrodynamic bearing, automatic control, wear and temperature decrease, data of main properties

\title{
HYDRODYNAMIC TILTING PAD JOURNAL BEARING WITH AUTOMATIC CONTROL
}

\begin{abstract}
Hydrodynamic three tilting-pad journal bearing is analyzed in the paper. It is shown that, when assembling that type of not controlled bearing, it is impossible to obtain a small clearance between the pad and the journal at high frequency of journal rotation. In a static state, i.e. when the journal is immobile, such a bearing should be assembled with a large interference between the pads and the journal in order to guarantee the small clearance at rotation. At start, when the hydrodynamic lubricating wedges between the pads and journal are absent, the bearing would work with dry friction, resulting in quick wear of pads and high load of the drive motor. Apart of that, it is impossible to control the power consumption and temperature regime neither for idle nor for working rotation of the journal. The proposed automatic control gives a possibility to regulate the clearance between the pads and the journal by measuring and controlling the axial force of the pad load, and in such a way to improve work conditions of the bearing.
\end{abstract}

\section{Introduction}

Hydrodynamic tilting-pad journal bearings are widely used in turbines, compressors, pumps and other machines where rotors are revolving for a long time without frequent start and stoppage. Their advantage consists in smooth and accurate revolving motion, good vibration damping properties, high stiffness, and service durability. Such bearings also are used for the spindles of cylindrical grinding machine where, thanks to their accurate rotation properties, the roundness accuracy of the parts being ground is as high as 0.1$0.3 \mu \mathrm{m}$, and the surface roughness is up to $\mathrm{Ra}=0.02 \ldots 0.04 \mu \mathrm{m}$ [1]. Calculation and analysis of different properties of such bearings are presented in many technical papers $[2,3,4,5$, etc.]. The analysis shows that work quality

*Vilnius Gediminas Technical University, LT-03224 Vilnius, Lithuania; E-mail: andma@vgtu.lt 
of such bearings depends on the fluid film thickness between the journal and the pad, which in turn depends on the change of oil temperature in the film at its squeeze between the journal and the pad during journal rotation.

One of simple designs of such bearings is the bearings with the pads supported by pivot pins adjusted in radial direction. At assembly of such bearing, the main difficulty is to define accurately the clearance between the pads and the journal, which significantly influences work quality of the bearing. Additionally, although the bearing is assembled correctly, deflections resulting from heating and increased temperature of bearing body, pins and pads, causes that the preset clearance can change, which could deteriorate work quality of the bearing. The practice shows, that, when assembling such bearings, the assembly workers strain the pads and the journal in order to achieve high stiffness, so that, at the start of revolutions, the bearing does not work as a hydrodynamic one, but as a semi-dry friction bearing. Only after revolving frequency increases, the oil is pulled into the gap between the journal and the pad, the film pressure increases, and in the result of pin and pad contact deformation the bearing begins to work as a hydrodynamic one. Initial bad lubrication leads to quick wear of the contact surface between the pad and the journal, geometry of the pad changes, and the work of the bearing worsens.

In the case when the bearings are used e.g. in grinding machines, the valuable property of the bearing would be the possibility to measure, with a help of the bearing, the radial grinding force and in this way to control the grinding process. Such possibilities can be achieved through automatic control of the force acting on the bearing in radial direction. In the design described in [6], the radial force acting on the pad was evaluated by direct measurement of longitudinal deformation of the pin supporting the pad. Measurement results depend not only on elastic, but also on thermal deformation of the pin, which makes it impossible to achieve a tolerable accuracy of force measurement. At moderate (not to mention a high) stiffness of the pin, the temperature change by $1{ }^{\circ} \mathrm{C}$ may cause the same deflection of the pin as a load of $1000 \mathrm{~N}$. High measurement accuracy is then impossible.

In our work [7], a different method was proposed for measuring forces acting on the bearing pads, aimed at excluding the influence of temperaturerelated deflection on measurement results. Not longitudinal, but bending deflections of the pin neck were used in this method. Elastic deflections were measured in an increased scale. One of disadvantages of the design was that there was not foreseen accurate location of the pin eccentricity alongside the longitudinal axis of the rotating spindle. In such a case, the tangent force of oil film created by the journal sliding in the bearing had an additional influence on bending of the pin neck. A new design is then proposed, in 
which the eccentricity of the neck can be set parallel to the rotation axis, and bending of the neck in the direction perpendicular to the axis does not influence measurement results. Apart of the radial grinding force measurement, the bearing can be used for measurement and automatic control of radial forces acting in the bearing.

\section{Bearing with automatically controlled clearance between the pads and journal}

Fig. 1a shows the scheme of such a design. Three self-aligning pads 1 of the bearing supporting the revolving journal 2 are assembled in the body 3 . One of the three pins, the pin 4 supporting the pad in radial direction, has an internal hole, and the measurement stick 5 is inserted into it with a clearance along its length, with an exception of its front end, where it is pressed and riveted in the pin head. The pin neck is eccentric with respect to the internal hole of the pin and it bends under the action of the axial force. The stick 5 turns by an angle in reference to the pin axis, its displacement is measured by the transducer 6 , whose output signal is used for controlling the bearing's work. Because the transducer measures deflection in the direction perpendicular to the pin axis, the longitudinal deformation of the pin due to thermal expansion does not influence the measurement results. For adjusting its initial position, the pin 4 is mounted in an additional threaded bush 7 . The use of two threaded bushes, 4 and 7, makes it possible to use them in final adjustment as a differential screw. After adjustment, both pieces are fixed by the counter nuts 8 .

The other pin, 9, is automatically adjusted. For this purpose, it is mounted on the balls, 11, within the body 10 . One side of the pin supports the pad 1 , the other side presses, through the rolls 12 , on the movable wedge 13 . Opposite side of the wedge is connected, through the rolls 14, with the self-aligning support 15 , whose spherical top is supported by the flange 16 . The wedge 13 is driven by the puller 17 connected with an automatic drive. The drive is controlled by the signals received from the transducer 6 . In forward motion of the wedge 13 (to the right side) the pin 9 is driven in the direction of the journal 2, in backward motion it is driven by the plate spring 18, compressed in axial direction. In such a way, one can control the hydrodynamic force acting on the pads. The third threaded pin, 19, after adjusting the position of its supported pad, is strongly fixed in the body 3 by means of the counter nut 20 with a sealer.

When the bearings are used as a machine tool spindle bearings e. $g$. of cylindrical grinders, the radial cutting force is measured as the difference between the previously set hydrodynamic force and its change during cutting. 
a)

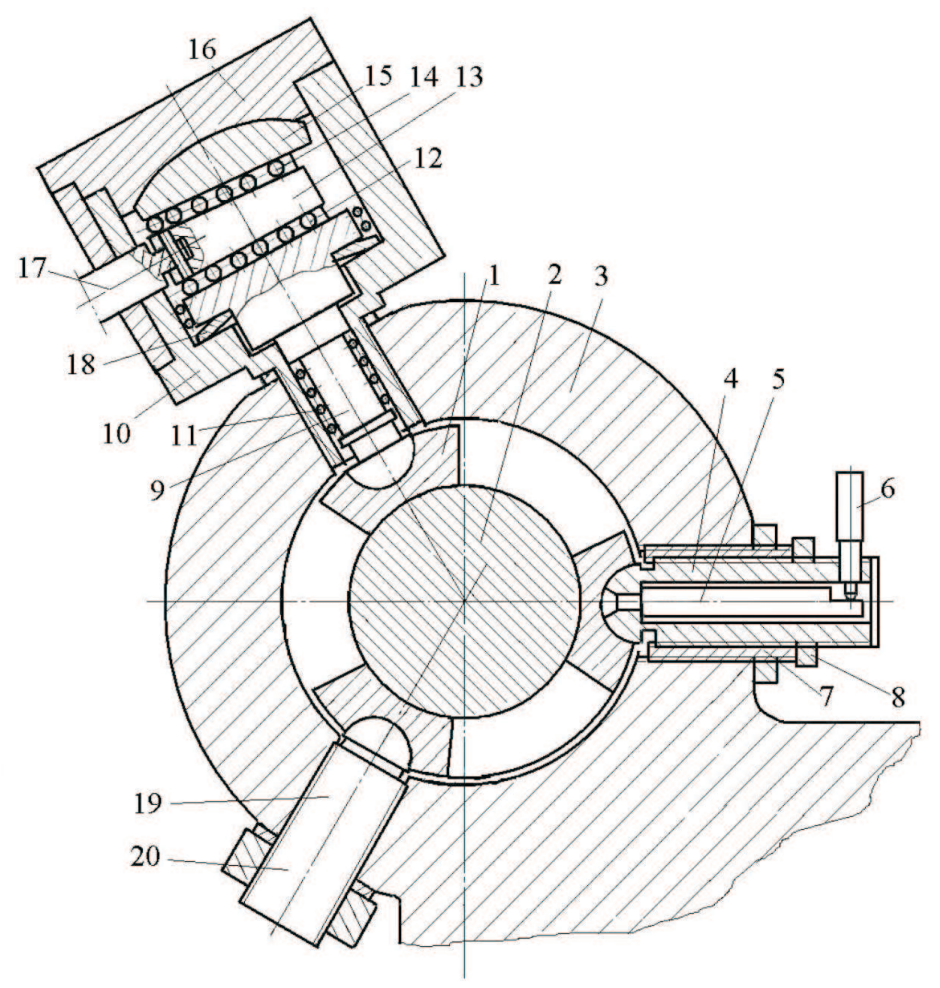

b)

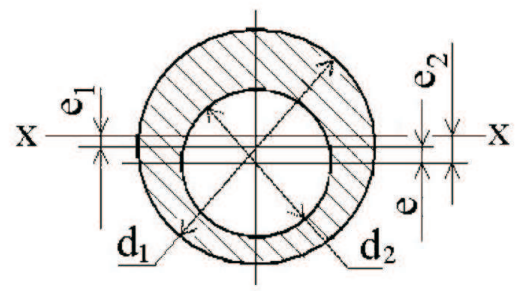

Fig. 1. Automatically-controlled bearing (a) and cross-section of eccentric neck of a pin (b)

\section{Analysis of the bearing work}

Fig. 1b shows the scheme of cross-section of the neck eccentric with respect to the internal hole of the pin (the stick 5 is not shown). At eccentric position of the external diameter $d_{1}$ of the neck with respect to the internal hole of diameter $d_{2}$, the neutral axis $\mathrm{x}$-x of the moment of inertia of the 
neck cross-section will be shifted upwards by the value $e_{1}$ from the axis of symmetry of the external diameter $d_{1}$ and by the value $e_{2}$ from the axis of symmetry of the internal diameter $d_{2}$. Eccentricity of the external diameter with respect to the internal diameter is equal $e$. Let us denote the moment of inertia of the area of external diameter $d_{1}$ above the axis $\mathrm{x}-\mathrm{x}$ by the letter $I_{1}$, the moment of inertia of the internal diameter $d_{2}$ by $I_{2}$, the moments of inertia of cross-section $d_{1}$ and $d_{2}$ between the axis $\mathrm{x}-\mathrm{x}$ and the axis of symmetry of these cross-sections by $I_{3}$ and $I_{4}$, respectively, and moments of inertia of the area of lower halves of the circles $d_{1}$ and $d_{2}$ by $I_{5}$ and $I_{6}$. One can see that the moment of inertia of the common area of the first part of cross-section placed over the axis x-x is equal to $I_{c 1}=I_{1}-I_{2}$, while that of the cross-section placed under the axis $\mathrm{x}-\mathrm{x}$ is equal to $I_{c 2}=I_{3}+I_{5}-I_{4}-I_{6}$. The diameters $d_{1}$ and $d_{2}$ and the eccentricity $e$ are known from the pin design. The eccentricity $e_{2}$ is equal to $e_{2}=e_{1}+e$, so there remains an unknown eccentricity $e_{1}$. Because

$$
I_{c 1}=I_{c 2}
$$

by insertion of values from $I_{1}$ to $I_{6}$ into equation (1) it is possible to find the value $e_{1}$, necessary for calculation of the moment of inertia of the area of neck cross-section.

One can express the moments of inertia, $I_{1}$ to $I_{6}$, with the following formulae:

$$
\begin{gathered}
I_{1(2)}=\frac{r_{1(2)}^{4}}{4}\left(\arccos \frac{e_{1(2)}}{r_{1(2)}}-\left(2 \frac{e_{1(2)}^{2}}{r_{1(2)}^{2}}-1\right) \frac{e_{1(2)}}{r_{1(2)}} \sqrt{1-\frac{e_{1(2)}^{2}}{r_{1(2)}^{2}}}\right) ; \\
I_{3(4)}=\frac{r_{1(2)}^{4}}{4}\left(\frac{\pi}{2}-\arccos \frac{e_{1(2)}}{r_{1(2)}}+\left(2 \frac{e_{1(2)}^{2}}{r_{1(2)}^{2}}-1\right) \frac{e_{1(2)}}{r_{1(2)}} \sqrt{1-\frac{e_{1(2)}^{2}}{r_{1(2)}^{2}}}\right) ; \\
I_{5(6)}=\frac{\pi r_{1(2)}^{4}}{8}+\frac{\pi e_{1(2)} r_{1(2)}^{3}}{4}+\frac{\pi e_{1(2)}^{2} r_{1(2)}^{2}}{2} .
\end{gathered}
$$

There $r_{1(2)}$ are radiuses of diameters $d_{1}$ or $d_{2}$ respectively; $e_{1(2)}$ are their eccentricities with respect to axis $\mathrm{x}-\mathrm{x}$. The moment of inertia of the common area $I_{c}$ of the neck cross-section about the axis $\mathrm{x}-\mathrm{x}$ is equal

$$
I_{c}=\frac{\pi}{4}\left(r_{1}^{4}+e_{1} r_{1}^{3}+2 e_{1}^{2} r_{1}^{2}-r_{2}^{4}-e_{2} r_{2}^{3}-2 e_{2}^{2} r_{2}^{2}\right) .
$$

Because the pin is loaded by the load going through its axis, and this axis coincides with the hole axis, it is necessary to find the action of axial load going through $e_{2}$ which is not coincident with the neutral axis $\mathrm{x}-\mathrm{x}$. The inertia 
moments, $I_{1}$ to $I_{4}$, are expressed by complicated equations, for this reason the value of $\mathrm{e}_{2}$ is calculated here by the method of approximation. In our case, $d_{1}=16, d_{2}=11, e=1 \mathrm{~mm}$. After calculation it was found that $e_{2}=3.58 \mathrm{~mm}$ $\left(e_{1}=2.08 \mathrm{~mm}\right)$. An axial load of $1 \mathrm{~N}$ creates a bending moment of $3.58 \mathrm{Nmm}$. The moment of inertia of the common area of the pin neck equals $I_{c}=2693$ $\mathrm{Nmm}^{4}$. The neck length is, in our case, $5 \mathrm{~mm}$. The length of the measurement stick from the pin head to the point of contact with the spindle of transducer, 6 , is $90 \mathrm{~mm}$. According to the simplified calculation, the axial load of 1 $\mathrm{N}$ creates an angular deflection of the pin head equal to $1.133 \cdot 10^{-8} \mathrm{rad}$, so the transducer 6 would measure a deflection of $1.02 \cdot 10^{-3} \mu \mathrm{m}$. Contemporary transducers can measure deflections as low as $0.01 \mu \mathrm{m}$, so the measurement method enables us to measure the load on the pad 1 (Fig. 1a) in the range of $10 \mathrm{~N}$.

The applied measurement method has not a great influence on the change of bearing stiffness. With the neck length $5 \mathrm{~mm}$ and its cross-section area $106 \mathrm{~mm}^{2}$ (as it was shown earlier, $d_{1}=16, d_{2}=11 \mathrm{~mm}$ ), the longitudinal elastic deflection of the pin will be $2.25 \cdot 10^{-7} \mathrm{~mm} / \mathrm{N}$, or its stiffness will be $c_{p}=4.45 \cdot 10^{6} \mathrm{~N} / \mathrm{mm}$. It is of the same order of magnitude as the stiffness of hydrodynamic oil film in the bearing.

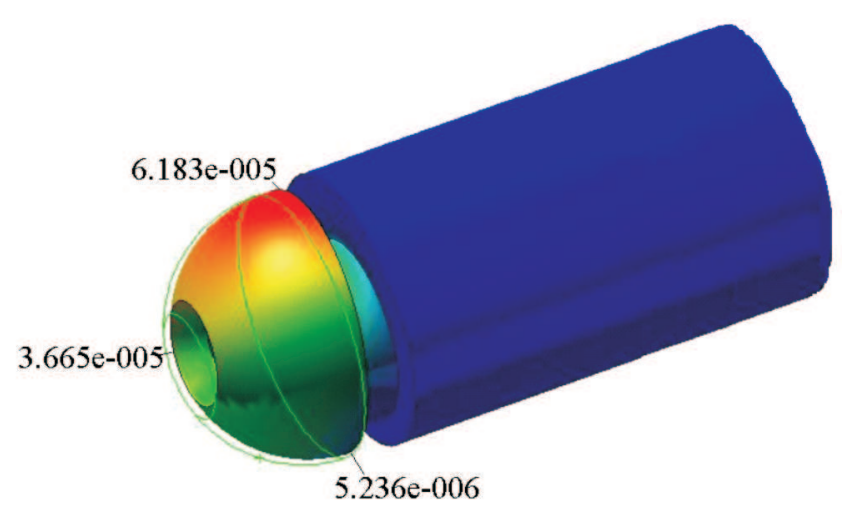

Fig. 2. Deflection of a pin head under load of $200 \mathrm{~N}$

Fig. 2 shows graphically represented pin deflection under the load of $200 \mathrm{~N}$, calculated by the finite element method. Because deflections values represented by colors would be hard to distinguish when printed in black and white, the deformation values at specific places are shown in numbers. The difference of deflections between two diametrically opposite points equals $(6.183 e-5)-(5.236 e-5)=5.659 e-5$ and with pin head diameter $24 \mathrm{~mm}$ the inclination angle will be $2.358 e-006$, or under the load of $1 \mathrm{~N}$ it will be $1.1977 e-008 \mathrm{rad}$. It is close to more simply calculated data, shown 
above. The displacement of $3.665 e-005$ at the center, obtained with a load of $200 \mathrm{~N}$, will be equal to $1.8235 e-007$ for a load of $1 \mathrm{~N}$. It differs from the calculated value mentioned above, but the discrepancy is the result of bending and longitudinal deflection.

The hydrodynamic radial force of oil film wedge $F_{0}(\mathrm{~N})$, created due to journal revolution, can be expressed on the grounds of the data [8] by equation

$$
F_{0}=5.1 \cdot 10^{-11} \mu \cdot n \cdot D \cdot B^{2} \cdot L \cdot C_{L} / \Delta^{2}
$$

where $\mu$ is oil viscosity coefficient in centipoises $(\mathrm{cP})$; $\mathrm{n}$ is revolving frequency of the journal rev/min; $D, B, L$ are diameter of the journal, width and length of the pad, respectively; $C_{L}$ is the coefficient given by formula $C_{L}=\frac{1.25}{1+(B / L)^{2}} ; \Delta$ is the value of clearance between the journal and the pad, in $\mathrm{mm}$.

Load-carrying capacity force $F_{3}$ (in $\mathrm{N}$ ) in radial direction arising in a three-pad journal bearing at displacement of a journal axis to eccentricity $e_{j}$ with respect to an equilibrium point (at the center of the bearing) is expressed by equation

$$
F_{3}=F_{0}\left(\frac{1}{(1-0.5 \chi)^{2}}-\frac{1}{(1+\chi)^{2}}\right)
$$

or stiffness $c_{j}$ of lubricant hydrodynamic wedge film is $c_{j}=F_{3} / e_{j} \mathrm{~N} / \mu \mathrm{m}$.

There $\chi=2 e_{j} / \Delta$, where $\Delta$ at this case is in $\mu \mathrm{m}$.

It is commonly accepted that lubrication oil for three pad journal bearings at high revolving frequency of a journal should have very small viscosity, approximately $4 \mathrm{cP}$ at temperature $55^{\circ} \mathrm{C}$. It coincides with the lubricant viscosity ISO 6, a little below the Shell Tellus oils Do 10 lubricant. Such is the oil И5A produced in Ukraine. Further calculations are done assuming the use of that oil. In our case, having the three pad bearing with journal diameter $D=70 \mathrm{~mm}$ and pad dimensions $B=36, L=55 \mathrm{~mm}$, the rotational speed of the journal $3000 \mathrm{rev} / \mathrm{min}$ and assuming the clearance $\Delta=0.01 \mathrm{~mm}$, the hydrodynamic radial force $F_{0}$ of the oil film wedge will be $26722 \mathrm{~N}$; the eccentricity $e_{j}=1 \mu \mathrm{m}$ produces the force $F_{3}$ equal to $14435 \mathrm{~N}$, the same value would have the bearing lubrication wedge stiffness, only in $\mathrm{N} / \mu \mathrm{m}$.

The stiffness $c_{c}$ of the contact between the spherical pin head and the pad sphere can be expressed by equation

$$
c_{c}=\frac{9.81 d_{s}^{2}}{16 k_{s}}
$$


where $d_{s}$ is diameter of a sphere; $k_{s}$ is a coefficient, $k_{s}=0.5 \mathrm{~mm}^{2} \cdot \mu \mathrm{m} / \mathrm{N}$. Assuming $d_{s}=24 \mathrm{~mm}$, we obtain $c_{c}=706 \mathrm{~N} / \mu \mathrm{m}$. The common stiffness $c_{\text {com }}$ of the pin head contact and the head neck can be found from the equation $\frac{1}{c_{c o m}}=\frac{1}{c_{c}}+\frac{1}{c_{p}}$, and it gives $c_{c o m}=609.3 \mathrm{~N} / \mu \mathrm{m}$.

If the clearance between the pad of pin 4 is assumed equal to $0.01 \mathrm{~mm}$ and the stiffness in that direction equals $1127 \mathrm{~N} / \mu \mathrm{m}$, the action of force $F_{0}=26722 \mathrm{~N}$ would deform the pin with the other contact and neck length elements to the value of $43.86 \mu \mathrm{m}$. In this case, after stoppage of journal revolutions (at static state), the clearance between the pad and the journal $0.01 \mathrm{~mm}(10 \mu \mathrm{m})$ disappears, but there will be left an elastic interference in the sphere of neck and journal contact $33.86 \mu \mathrm{m}$, or the pads would load the journal with a force of $20630 \mathrm{~N}$ and at such a load the journal should start revolving. The dry or semi dry friction conditions would be at such a start, starting friction moment and wear of pads would significantly increase. For that reason, the bearing which is not automatically controlled could not work with lubricating oil wedge of $0.01 \mathrm{~mm}$ thickness because, in order to secure such a film thickness, a large initial interference in the pin structure must be introduced. The zero interference $\left(F_{i n}\right)$ force in that structure would guarantee the minimal gap $\Delta$ at which the maximal stiffness of lubricant film is obtained, and the revolving journal can start without increased friction force in the bearings. Such interference can be found from equation

$$
F_{\text {in }}=F_{0}-c_{\text {com }} \Delta=0 .
$$

The graphs in Fig. 3a show the dependence between $F_{0}, F_{3}$ and $F_{\text {in }}$ calculated by equations 4 and 7 , respectively. It can be seen that, for $F_{\text {in }}=0$, the clearance $\Delta$ between the pad and the journal revolving with rotational speed of $3000 \mathrm{rev} / \mathrm{min}$ should be approximately $0.0164 \mathrm{~mm}$, at these conditions the hydrodynamic wedge would create the force $F_{0}=10000 \mathrm{~N}$, and the force $F_{3}$ at eccentricity $e_{j}=1 \mu \mathrm{m}$ of the journal with respect to the bearing axis is approximately $3300 \mathrm{~N}$, so the wedge stiffness is $3300 \mathrm{~N} / \mu \mathrm{m}$. With such a clearance $\Delta$ foreseen at journal revolution, the bearing can be assembled without any initial interference and any clearance between the pads and the journal. With higher value of $\Delta$, the bearing should be assembled at a static position (the journal not revolving) with a clearance between the pads and the journal.

The stiffness of the movable pin 9 and the contact of the unmovable pin 19 sphere and their pads is the same as of pin $4-c_{c}=706 \mathrm{~N} / \mu \mathrm{m}$. However, for the pin 9, one must take into count longitudinal deflection of that pin and deflections of contact between the pin 9 and rollers 12, wedge 13, rollers 14 , sphere 15, and the contact between the sphere and the flange 16. Additional 
a)

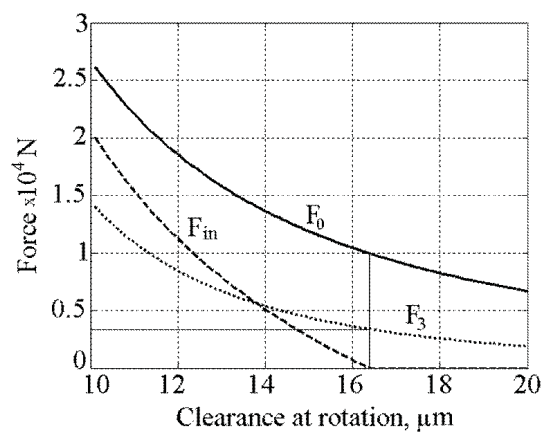

b)

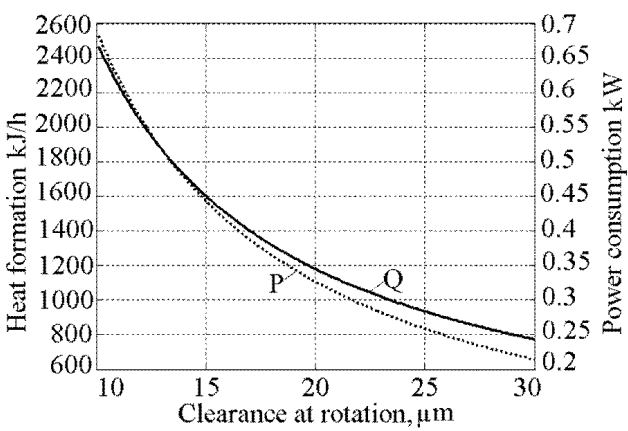

Fig. 3. Acting forces (a) and heat formation and power consumption

(b) dependence on clearance between the pad and the journal at journal rotation

calculations of it are not shown in this paper, but it was found that longitudinal stiffness of the pin 9 is $980 \mathrm{~N} / \mu \mathrm{m}$, the contact stiffness of double roller ways with rollers 11 and 13 is about $660 \mathrm{~N} / \mu \mathrm{m}$, keeping in mind that they are loaded by the plate spring 18 and the hydrodynamic pressure with common load of approximately $26000 \mathrm{~N}$. The contact stiffness of the contact between the sphere 15 and the flange 16 can be found from equation (6) assuming the sphere diameter $100 \mathrm{~mm}$; it is equal to $6100 \mathrm{~N} / \mu \mathrm{m}$. The common stiffness of all connections of the pin 9 in such a case is equal to $370 \mathrm{~N} / \mu \mathrm{m}$.

The common stiffness of the unmovable pin 19 is $667 \mathrm{~N} / \mu \mathrm{m}$. One must keep in mind that its sphere is connected with the body by the neck of $4 \mathrm{~mm}$ length and $20 \mathrm{~mm}$ diameter.

Because the three pins (Fig. 1) are inclined one to the other by an angle of $120^{\circ}$ and act as a gang of springs, the common stiffness of pins in any specific pin direction will be equal to a vector sum of all stiffness components of mechanical parts in that direction. So, the common stiffness in the direction of pin 4 will be $1127 \mathrm{~N} / \mu \mathrm{m}$, in the direction of pin $9-1008$ $\mathrm{N} / \mu \mathrm{m}$, in the direction of pin $19-1156 \mathrm{~N} / \mu \mathrm{m}$. For a bearing that is not automatically regulated, the stiffness of pins in all three directions would be $1334 \mathrm{~N} / \mu \mathrm{m}$, it means that the stiffness of pins would be higher, but there won't be any possibility to assemble the bearing with a desirable initial interference or clearance between the journal and the pads. Other possibilities of automatically-regulated bearing will not exist, either.

Of course, the intention is to obtain the possibility to increase the stiffness of elements of an automatically-controlled bearing.

With a clearance of $0.0164 \mathrm{~mm}$, the hydrodynamic wedge stiffness is $3300 \mathrm{~N} / \mu \mathrm{m}$, the stiffness of mechanical parts in the direction of pin 4 is equal to $1127 \mathrm{~N} / \mu \mathrm{m}$, and the common stiffness in that direction is $830 \mathrm{~N} / \mu \mathrm{m}$. 
Although, as we can see in Fig. 2a, the stiffness of the lubricant layer (curve $\mathrm{F}_{3}$ ) can vary in a large range, apart of that, the initially set interference or clearance value can change remarkably due to the heat produced in the bearing, and the bearing would work in conditions different from the preset ones. E.g., to have the diameter of journal 2 equal to $\varnothing 70 \mathrm{~mm}$ (Fig. 1), the hole diameter in the body 3 should not be lower than $112 \mathrm{~mm}$; for a change of temperature of the bearing parts by $1^{\circ} \mathrm{C}$, the thermal deflections on that size would be $1.2 \mu \mathrm{m}$; as it is seen from Fig. 2, such a change can significantly influence the force $\mathrm{F}_{0}$ or $\mathrm{F}_{3}$. It should be stressed that, e.g. in our research [1], we found that the temperature of lubricating oil in working bearing changed from room temperature $18^{\circ} \mathrm{C}$, at the moment of starting, to $41^{\circ} \mathrm{C}$ after two hours of idle work. The temperature of the spindle body during this time increased up to $43^{\circ} \mathrm{C}$; the oil temperature at the inlet to oil radiator was $39^{\circ} \mathrm{C}$, at the outlet from the radiator $25.5^{\circ} \mathrm{C}$. In the application of the bearing for a grinding machine which works with start and stoppage of the cooling liquid, the start and stoppage also influence thermal deflections, and it is very difficult to say how large is the variance of thermal deflection in the bearing's parts. Because it is difficult to assemble the bearing with the journal with necessary setting of the initial interference or clearance between the pins and the journal and, apart of that, the bearing can be started to revolve not only in the cold state (at room temperature), but also in the conditions of increased temperature, and it is not known at what conditions (with what interference or clearance between the journal and pads) the journal starts revolving, it is impossible to guarantee low wear and good work conditions of the bearing. Such problems do not appear in automatically-controlled bearings because, at the start of journal rotation, the journal can be released from the interference, and after the start the necessary clearance can be controlled.

\section{Other possibilities of bearing use}

An automatically-controlled bearing makes it possible not only to control the bearing stiffness, its work accuracy, to control machining forces in machine tools, but at the same time to decrease heating of the bearing and to control the necessary idle power of its revolution. When the bearing is used e.g. for grinding machine, at grinding work the bearing can work with a smaller clearance $\Delta$ between the journal and the pads, while at idle work this clearance can be increased. According to the data from [8], at the sliding speed of the journal of up to $10 \mathrm{~m} / \mathrm{s}$, the main power $P$ loss is due to friction in the carrying lubricant layer. The power $P_{1}$ for one pad is expressed by equation 


$$
P_{1}=5.45 \cdot 10^{-15} \frac{\mu n^{2} D^{2} B L C_{f}}{\Delta(1+\chi \cos \Theta)},
$$

the heat generated by that power is expressed by equation

$$
Q_{1}=196.93 \cdot 10^{-13} \frac{\mu n^{2} D^{2} B L C_{f}}{\Delta(1+\chi \cos \Theta)},
$$

there $P$ is expressed in $\mathrm{kW}, Q-$ in $\mathrm{kJ} / \mathrm{h}$; the value $C_{f}$ in both cases equals $C_{f}=1+0.1 C_{L}$.

Fig. $3 \mathrm{~b}$ shows the dependence of heat generation and the power loss in one bearing versus the clearance $\Delta$ value at journal revolution. Because there is a pair of bearings - one of them on one side of a rotor, the other on the other side, the heat generation and power loss will be doubled. It can be seen that, when the clearance $\Delta$ changes from $0.01 \mathrm{~mm}$ to $0.03 \mathrm{~mm}$, the power loss decreases from approximately 0.68 to $0.21 \mathrm{~kW}$ in one bearing, while heat generation changes from 2500 to $750 \mathrm{~kJ} / \mathrm{h}$. Because specific heat of the lubrication oil is $1.67 \mathrm{~kJ} / \mathrm{kg} \mathrm{K}$, the oil in a $20 \mathrm{~kg}$ tank would be heated to $22.5^{\circ} \mathrm{C} / \mathrm{h}$. For a pair of bearings, it would be twice as much. As it was shown above, the lubricating oil flowing through the radiator is efficiently cooled by a fan blowing air through it; nevertheless, the oil temperature significantly changes in time. The use of automatically-controlled bearing makes it possible to ensure the best regimes for working and idle operation of the bearing, aimed at working with higher journal revolving accuracy, lower heating and power losses in the bearing. Measuring and control of the cutting forces at the use of the bearing in machine tools makes it possible to increase machining accuracy and productivity.

\section{Conclusion}

The design of a hydrodynamic three-tilting-pad journal bearing with automatic control of hydrodynamic forces acting in the bearing enables one not only to control hydrodynamic forces in the bearing, but also, when the bearing is used in machine tools as a spindle bearing, e.g. of grinders, to control the radial cutting force. Hydrodynamic forces are controlled by regulating the clearance between the pads and the journal. The cutting forces are controlled as a change of previously defined hydrodynamic forces. Maintaining the necessary clearance value also makes it possible to control the heat generation and power consumption in the bearing. 


\section{REFERENCES}

[1] Marcinkevičius A. H.: Stabilization of Grinding Processes and Machine Tool Work. Vilnius, Technika, 1995 (in Lithuanian).

[2] Santos I. F.: On the Adjusting of the Dynamic Coefficients of Tilting-Pad Journal Bearings, Tribology Transactions, Vol. 38, Iss. 3, July 1995, pp. 700-706.

[3] Reddy D. S. K., Swarnamani S., Prabhu B.S.: Thermoelastohydrodynamic Analysis of Tilting Pad Journal Bearing-Theory and Experiments, Tribology Transactions, Vol. 43, Iss. 1 Jan. 2000, pp. 82-90.

[4] Hori Y.: Hydrodynamic Lubrication, Springer Verlag, Tokio, 2006.

[5] Vekteris V. J.: Adaptive Tribological Systems, Vilnius, Technika, 1996.

[6] Marcinkevičius A. H. J.: Multi Pad Self Aligning Bearing with Automatic Control, USSR Certificate of Invention No 746135, 1977 (in Russian).

[7] Marcinkevičius A. H. J.: Multi Pad Self Aligning Bearing and Method of its Assembly, USSR Certificate of Invention No 1624221, 1994 (in Russian).

[8] Reshetov D. N.: Parts and Mechanisms of Metal Cutting Machine Tools, Maschinostroenye, Moscow, 1972 (in Russian).

\section{Łożysko hydrodynamiczne $\mathrm{z}$ panewką z ruchomymi płytkami ze sterowaniem automatycznym}

\section{Streszczenie}

Praca dotyczy analizy warunków pracy łożyska hydrodynamicznego z panewką z ruchomymi płytkami ze sterowaniem automatycznym. Pokazano, że bez sterowania nie jest możliwe zapewnienie małej szczeliny pomiędzy płytką a czopem przy obrotach wału z dużymi prędkościami. $\mathrm{W}$ warunkach statyki, gdy wał pozostaje w spoczynku, łożysko takie powinno być montowane $\mathrm{z}$ dużym luzem ujemnym pomiędzy płytkami i czopem aby zagwarantować małą szczelinę przy obrotach wału. W początkowym okresie pracy łożyska, przy braku klina smarnego, łożysko mogłoby pracować w warunkach tarcia suchego co prowadzi do szybkiego zużycia płytek i dużego obciążenia napędu. Ponadto nie jest możliwe sterowanie zużyciem energii ani warunkami temperatury w której pracuje łożysko zarówno bez jak i pod obciążeniem. Zaproponowane sterowanie daje możliwość regulacji szczeliny pomiędzy płytkami i czopem poprzez pomiar and sterowanie siłą osiową obciążającą płytkę, co prowadzi do polepszenia warunków pracy łożyska. 